\title{
DESCRIPTIVE STUDY OF THE INTEGRATION OF SUSTAINABILITY IN AN ENGINEERING COURSE
}

\author{
Lou GRIMAL, Claudine GILLOT, Tatiana REYES, Nadège TROUSSIER, Pauline MARTY \\ and Sabrina BRULLOT \\ InSyTE, CREIDD, Université de Technologie de Troyes, France
}

\begin{abstract}
Education on sustainability is one of the main concerns of the $21^{\text {st }}$ century for engineers, it is indeed engineers design technologies and participate actively to industrial activities, their education to design for sustainability is paramount. In the literature, engineering skills for sustainability are well identified. Also, pedagogical experiments on the integration of these competences in engineering curricula are reported. This article describes, in a pedagogical situation the modelling of interactions between a technical system, human organizations and the biosphere. The article analyses whether this type of representation can allow students to acquire certain engineering skills for sustainability.
\end{abstract}

Keywords: Engineering education, sustainability, competencies for sustainability, interaction

\section{INTRODUCTION}

As a pressing concern, education on sustainability is important. As engineers design technologies and participate actively to industrial activities, their education to design for sustainability is paramount [1]. Since the beginning of the century this challenge is studied, and two different bodies of work are identified.

The first piece of work consists of the research on the meaning of integrating sustainability in design engineering education, and the main skills and competencies to address ([2], [3]). As discussed in Quelhas et al [4], there are different skills to consider when it comes to design engineers' education on sustainability. It also finds an echo in the twelve questions to address the integration of sustainability in engineering curricula identified in [5], and classified in four main topics: implemented practice, subjects and objects of the practice, (other) stakeholders, outcome or results. This model is placed in Engeström's general model of an Activity System which distinguishes Instruments, Subjects, Objects, Rules, Community, Division of Labour and Outcome as structuring elements of practice [6]. The proposal from [4] is specifically dedicated to education in engineering and provide identified cross-disciplinary competencies for sustainability education, which are: critical thinking, working in an interdisciplinary group (collaboration), ability to solve problems (integrated resolution), system thinking, normative competence, self-knowledge, contextualization and vision of the future (anticipatory), strategic competence. [3] uses this model and completes it with specific engineering skills on knowledge and understanding of engineering skills, engineering analysis, engineering design, investigations, engineering practice, making judgements, communication and team working, lifelong learning.

The second piece of work consists of a descriptive study of experiments in educating engineers for sustainability. Case studies are documented and analysed using a specific assessment grid to evaluate the way education for sustainability is reached but also encounters specific difficulties. Many research papers discuss these topics such as [7], [8], [5], [9], [10], [11], [12], [13]. All these descriptive studies are required to experiment and share in order to identify best practices and common assessment framework. Our paper is positioned in this second body of work. Indeed, our work uses a grid from the first body of work (competences from Quelhas [4]) to evaluate the relevance of the pedagogical model. This work describes a learning situation and its evaluation by the competences acquired by the students following the pedagogical model. Indeed, this paper identifies a competencies framework inspired from [4], and describes a French experiment of introducing a specific pedagogical module on sustainability in the engineering curricula at the University of Technology of Troyes in France. Based on the experiment assessment, our paper discusses the interest of a proposed model which represents interactions between humans, a technical system and nature (H-TS-N model). This representation allows 
engineers to understand three elements: the planetary limits (i.e., what humans take from the biosphere to design the technical system, with potential thresholds not to be exceeded), fundamental human needs and the functioning of socio-technical organizations within these physical limits and social needs - all those being a preliminary to design socio-technical systems in a responsible way. The H-TS-N model is therefore evaluated by the competence grid proposed by Quelhas.

As the acquisition of the 8 competences presented by Quelhas [4] seem necessary (but maybe not sufficient) to address sustainable design, this paper explores a model (the H-TS-N) to identify if it can be used in engineering education to future engineers creating technical systems for sustainable futures.

\section{EXPERIMENT}

The pedagogical module presented and tested in this article is the "representation and modelling H-TS$\mathrm{N}$ " pedagogical module. The aim of this course is for the students to model the interactions between humans, technical systems and nature according to several spatial scales. The course took place asynchronously and in English. The asynchronous format was a choice from the very beginning of the course design and not an obligation due to the health situation in 2020. So, it means there was no synchronous session of class or tutorial. This asynchronous format allows us to open the course to several curricula and allow students to be involved in an interdisciplinary project group. This course was open to 3 engineering curricula at the University of Technology of Troyes (mechanical, materials, and mechanical and materials in a professional training curriculum) and a total of 57 students attended. The students had online classes (several modules dedicated to knowledge transfer), practical works to do each week on the Moodle pedagogical platform, and a final deliverable of the H-TS-N interactions. The representation of the H-TS-N interactions was carried out by means of a graphical representation in the form of a table. This model, only briefly presented in this paper, is a preliminary model that will be improved following feedback from students who have worked with it.

The concepts of the model are as follows:

- The life cycle: the life cycle stages dissect the different stages in the lifespan of a technical system and details it. Students are then compelled to cope with social and ecological consequences of design choice usually made for the use stage on the other stages (raw materials extraction, production and end of life).

- Scales: three levels of scale are present (macro, meso, micro). These scales are to be defined by the students. The levels cover individual level as well as cultural level.

- Interactions: the interactions between the three parts (human, technical system, nature) are present in pairs in the table (TS-N, N-H, TS-H).

- Causes / consequences: the information is structured according to the causes and consequences of the interactions. The consequences refer to the impacts of said interactions.

Those different concepts are not (or only partially) mentioned in the other modules of students. Indeed, life cycle assessment can be seen in one other courses, which is not mandatory. Multi-level impacts ("scales") and the notion of interactions are not addressed in other modules of the curriculum. The aim of the article is to evaluate the acquisition of competences on sustainability by engineering students through this course and thus throughout the H-TS-N model.

\section{METHODOLOGY}

To evaluate the relevance of the H-TS-N model to help students acquire competences, we developed an analysis grid. The data collected for the analysis is: the evaluation of the students' productions by the pedagogical team, and an online survey for the students who followed the entire course in the fall of 2020 (an online questionnaire of 28 questions and a group interview).

In order to construct an analysis grid of the skills acquired by students during the pedagogical module, we started with the article from [4]. These eight "competences for sustainability" of [4] are considered in our article as "macro competences". From these macro competences, we have deduced competences (in the sense of an ability to act in a complex environment [14]). In order to be able to assess these competences, we have developed indicators and different levels of validation of those indicators. Table 1 shows the different macro competences, competences and indicators. Levels of validation were implemented for every indicator, e.g., "Questioning the structure of the H-TS-N model". This indicator has 4 different levels of validation: no express of critical thinking / not enough data to know (level 1), some criticism expressed but not shared within the project group (level 2), criticism expressed and 
discussed among the project group (level 3), criticism expressed, and change implemented in the structure of the model (level 4). The first 8 questions of the online questionnaire were used to fill in the levels of validation.

In developing this grid, using the objectives of the teaching module, we identified that this course could only help students partially acquire 6 of the 8 competences mentioned by [4]:

1. Critical thinking: the students had to analyse a socio-technical system they were interested in. The analysis of the H-TS-N interactions forces the students to question their initial vision of the system under study, as well as selecting and justifying the sources on which they rely.

2. Work in an interdisciplinary group: the project groups are comprised of engineers from different curricula at several levels: the students' disciplinary field (mechanics, materials, or both), the level of study (3rd or 5th year), the type of study (in a professional training contract or not).

3. Systemic thinking: students had to identify, understand and formalize interactions between different technical systems (a car wheel and a road for instance) in different perspectives (i.e., different scales), and this competence has been present during the entire course.

4. Normative competence: students were expected to explain the current standards and question them in relation to the basic needs that were presented to them in class.

5. Self-knowledge competence: students were expected to question the role of engineers in the design of the technical system (when relevant).

6. Contextualization and vision of the future: students were expected to contextualize the current situation (by the description of the H-TS-N interactions).

To give you an example of the grid, here are 3 macro competences (Table 1).

Table 1. Analysis grid (only 3 competences)

\begin{tabular}{|c|c|c|}
\hline $\begin{array}{l}\text { Macro } \\
\text { competence }\end{array}$ & Competence & Indicators \\
\hline \multirow{3}{*}{$\begin{array}{l}\text { Critical } \\
\text { thinking } \\
\text { MC-A }\end{array}$} & $\begin{array}{l}\text { Ability to question the structure of } \\
\text { the proposed H-TS-N model - A1 }\end{array}$ & $\begin{array}{l}\text { Questioning the structure of the H-TS-N model } \\
\text { - A1a }\end{array}$ \\
\hline & $\begin{array}{l}\text { Ability to complete the model with } \\
\text { critical thinking - A2 }\end{array}$ & $\begin{array}{l}\text { Process for questioning the information } \\
\text { collected to complete the H-TS-N model - A2a }\end{array}$ \\
\hline & $\begin{array}{l}\text { Ability to step back and detach } \\
\text { oneself from the H-TS-N model - } \\
\text { A3 }\end{array}$ & $\begin{array}{l}\text { Approach the H-TS-N model differently. The } \\
\text { model remains a possible form of } \\
\text { representation. - A3a }\end{array}$ \\
\hline \multirow{8}{*}{$\begin{array}{l}\text { Working in } \\
\text { an } \\
\text { interdisciplin } \\
\text { ary group } \\
\text { MC-B }\end{array}$} & \multirow{3}{*}{$\begin{array}{l}\text { Ability to interact in an } \\
\text { interdisciplinary context - B1 }\end{array}$} & Check the diversity of profiles - B1a \\
\hline & & $\begin{array}{l}\text { Effectiveness of interactions between students } \\
\text { in a project group - B1b }\end{array}$ \\
\hline & & $\begin{array}{l}\text { Frequency of interaction between students } \\
\text { from different project groups - B1c }\end{array}$ \\
\hline & \multirow{2}{*}{$\begin{array}{l}\text { Ability to exchange with empathy } \\
\text { with people who are not from the } \\
\text { same academic background - B2 }\end{array}$} & Conflict resolution/empathy - B2a \\
\hline & & $\begin{array}{l}\text { Quality of interactions (between members of } \\
\text { the same group) - B2b }\end{array}$ \\
\hline & \multirow[t]{3}{*}{$\begin{array}{l}\text { Ability to organize effectively with } \\
\text { people from different backgrounds } \\
\text { - B3 }\end{array}$} & $\begin{array}{l}\text { Ability to identify the skills of group members } \\
\text { - B3a }\end{array}$ \\
\hline & & Quality of collective productions - B3b \\
\hline & & Organization within the group - B3c \\
\hline \multirow[t]{2}{*}{$\begin{array}{l}\text { Systemic } \\
\text { thinking MC } \\
\text { - C }\end{array}$} & $\begin{array}{l}\text { Ability to identify and represent the } \\
\text { complexity of one or more H-TS-N } \\
\text { interactions - C1 }\end{array}$ & $\begin{array}{l}\text { The process of understanding the elements that } \\
\text { compose a technical system and its interaction } \\
\text { with other technical systems. - Cla }\end{array}$ \\
\hline & $\begin{array}{l}\text { Ability to identify an interaction as } \\
\text { a whole - C2 }\end{array}$ & $\begin{array}{l}\text { Understand an interaction in its context with } \\
\text { all of the following elements: social, cultural, } \\
\text { environmental, commercial, legal and political. } \\
\text { - C2a }\end{array}$ \\
\hline
\end{tabular}




\begin{tabular}{|l|l|l|}
\hline & $\begin{array}{l}\text { Understand the definition of an interaction } \\
\text { (reciprocal reaction of two phenomena on each } \\
\text { other) - C2b }\end{array}$ \\
\cline { 2 - 3 } & $\begin{array}{l}\text { Ability to link different parts of the } \\
\text { model (e.g., between scales or } \\
\text { between interactions) - C3 }\end{array}$ & $\begin{array}{l}\text { Links between the different elements of the } \\
\text { model - C3a }\end{array}$ \\
\hline
\end{tabular}

\section{SURVEY AND RESULTS}

The survey was conducted after the final project was submitted by students. There was 1 questionnaire of 28 questions and 1 group interview. 30 students answered the questionnaire of 28 questions (20 students answered during the group interview, 10 students answered the following week). During the group interview, the pedagogical team (1 associated professor and $3 \mathrm{PhD}$ students) and 20 students (out of 57) were present. The goal of the group interview was presented like this to the students: a discussion to find out the major difficulties they had experienced during the semester.

To give a general overview, students' groups worked on very different socio-technical objects: a bottle of champagne, a car wheel, a battery for electric cars or robot for agricultural activities.

Table 2. Results of each macro competence

\begin{tabular}{|c|c|}
\hline Macro competence & Results \\
\hline Critical thinking & $\begin{array}{l}\text { The students became critical of the technical system they were studying but did } \\
\text { not criticize the H-TS-N model as such. No real change in the H-TS-N model } \\
\text { structure was implemented. }\end{array}$ \\
\hline $\begin{array}{l}\text { Working in an } \\
\text { interdisciplinary } \\
\text { group }\end{array}$ & $\begin{array}{l}\text { Only } 5 \text { out of } 12 \text { project groups are made up of students with different profiles, } \\
\text { which limits the development of this skill. Moreover, interactions between the } \\
\text { different groups were generally weak and did not allow for the creation of other } \\
\text { interdisciplinary situations. It was found that the students had a medium ability to } \\
\text { interact in an interdisciplinary context. } \\
\text { We can add that the lockdown situation may have had an effect on the quality of } \\
\text { student interaction. }\end{array}$ \\
\hline Systemic Thinking & $\begin{array}{l}\text { Systemic thinking competence is partially acquired: most of the project groups } \\
\text { described interactions, sometimes quite complex, but no group was able to } \\
\text { describe a global vision of the technical system. }\end{array}$ \\
\hline $\begin{array}{l}\text { Normative } \\
\text { competence }\end{array}$ & Most of the students did not explain the current standards they were expected to. \\
\hline Self-knowledge & $\begin{array}{l}\text { The majority of the students did not integrate the role of the engineer in their } \\
\text { model and did not question this role in the interactions described. }\end{array}$ \\
\hline $\begin{array}{l}\text { Contextualization } \\
\text { and vision of the } \\
\text { future }\end{array}$ & $\begin{array}{l}\text { More than half the students who answered the survey acquired a broader vision of } \\
\text { a technical system (see the current impacts of technical systems on humans and } \\
\text { the biosphere) but did not project this vision into their future activity of design. }\end{array}$ \\
\hline
\end{tabular}

\section{DISCUSSIONS}

\subsection{Model's contribution}

The H-TS-N model enabled students to acquire 2 major competencies from the Quelhas model [4]: systems thinking and contextualization (the latter being included in the competency "contextualization and vision of the future", the vision of the future not being developed in this pedagogical module).

Three competences which are critical thinking, normative competence, self-knowledge, could be acquired thanks to this model but have not been developed by the students because a specific pedagogical integration would have been necessary (for instance having a "vision of the future", some specific pedagogical sessions should have been implemented).

27 students answered the question, "Why do you think you made this model? Why did you get out of it?" and all the answers were similar in their meaning "This makes it possible to realize that our actions have an important role to play, whether on the environment or on mankind. The use of a technical system, its manufacture and recycling not only have an impact on our own scale but also on a global scale." (answer of 1 student). Thus, this model encourages systemic thinking and an ability to 
contextualize, but not critical thinking. Also, the normative competence was usually forgotten and no real thought on the nature of engineering work could be seen in the final deliverables.

We can thus conclude overall that this model is a good way to improve engineering students' competences on sustainability but that several changes would increase its pedagogical efficiency.

\subsection{Future perspectives: modification of the pedagogical module}

\subsubsection{Path to a better acquisition of competences}

The development of critical thinking could be achieved by better linking the impacts of technical systems on the biosphere and human organizations at different scales, thanks to the different modules of the course. Some students described all the different deleterious consequences of a technical system on the biosphere and humans but finally concluded on the very positive aspect of the technical system. The gap between what they described, and the conclusion was substantial and might be a sign of a lack of critical thinking or cognitive dissonance.

Normative competence and self-knowledge could be developed by clearly asking student more clearly to integrate the role of the engineer in the design of a technical system. This could be integrated into the rating scale. Also, integrating the status of engineers in the model, would force students to question their future role in society, and might help their critical thinking.

Competences around the issue of interdisciplinarity could also be improved by integrating engineers from the curricula in computer science, networks, telecommunications and logistics. However, this interdisciplinarity will remain limited by the fact that students are in engineering training. Also, we could improve the evaluation of this competence by carrying out a cross-evaluation to measure the personal investment of each individual within the groups and thus confirm if they have efficiently contributed, as done by [15].

\subsubsection{Exploring graphic representation}

At first, the H-TS-N modelling as a table seemed to be a valuable representation (because it allows a real holistic view of the causes and consequences of a technical system at different levels of scales and stages). However, this graphic representation becomes a complex and hard table to summarize when filled. This is the reason why students offered alternative representations: (1) "Concerning the representation, I would have liked the [H-TS-N] table to be presented in a pie chart form with a stage of the life cycle on each sub-section, subdivided according to interactions (in a way derived from the climate collage ${ }^{l}$ presented at the beginning of the course)". (2) "The graphic representation is interesting to organize the different ideas in place, I found that once filled out the model is quite unreadable. A more pictorial or mind map representation would be more visual."

However, this table remains a valid tool for appropriating the different levels of impact, as it clearly displays the interactions between the technical system, human organizations and the biosphere. It allows a greater understanding of those phenomena and therefore a better quality of knowledge acquisition on the technical system studied as well as a better systemic vision.

Also, one of the limitations of the model is the absence of time dimension.

\subsubsection{Modification of skills assessment}

According to Quelhas' article [4], critical thinking is reflected in our own values, precepts and actions and allows us to take a stand on the discourse of sustainability. In the course, it is an aspect of critical thinking that we have not evaluated (by omission) and that we will include in the next session.

\subsubsection{Data collection}

In the questionnaire to assess students' skills at the end of the semester, several aspects were present in the same question and only partial answers were given. Also, we poorly anticipated the lack of precision in the answers that forced us to set aside some questions from the analysis. For the next session, we will improve our questionnaire which will allow us to integrate all the answers in our assessment.

\section{CONCLUSIONS}

Overall, the students developed a global vision of the interactions between the technical system, human organizations and the biosphere. The didactic aspect of the course (and the H-TS-N model) seems to be

\footnotetext{
${ }^{1}$ https://climatecollage.org/
} 
relevant, but a better pedagogical integration will be necessary during the second iteration of the course. Indeed, modifications planned in the 5.2 section will be integrated to the course. Also, integrating the status of engineers in the model, would force students to question their future role in society, and might help their critical thinking.

\section{REFERENCES}

[1] Meyer M. W. and Norman D. 'Changing Design Education for the 21st Century', She Ji: The Journal of Design, Economics, and Innovation, vol. 6, no. 1, pp. 13-49, Mar. 2020, doi: 10.1016/j.sheji.2019.12.002.

[2] Abd-Elwahed M. S. and Al-Bahi A. M. 'Sustainability awareness in engineering curriculum through a proposed teaching and assessment framework', Int J Technol Des Educ, Feb. 2020, doi: 10.1007/s10798-020-09567-0.

[3] Perpignan C., Baouch Y., Robin V., and Eynard B. 'Engineering education perspective for sustainable development: A maturity assessment of cross-disciplinary and advanced technical skills in eco-design', Procedia CIRP, vol. 90, pp. 748-753, Jan. 2020, doi: 10.1016/j.procir.2020.02.051.

[4] Quelhas O. L. G. et al. 'Engineering education and the development of competencies for sustainability', International Journal of Sustainability in Higher Education, vol. 20, no. 4, pp. 614-629, Jan. 2019, doi: 10.1108/IJSHE-07-2018-0125.

[5] Thürer M., Tomašević I., Stevenson M., Qu T., and Huisingh D. 'A systematic review of the literature on integrating sustainability into engineering curricula', Journal of Cleaner Production, vol. 181, pp. 608-617, Apr. 2018, doi: 10.1016/j.jclepro.2017.12.130.

[6] Engeström Y. and Sannino A. 'Studies of expansive learning: Foundations, findings and future challenges', Educational Research Review, vol. 5, no. 1, pp. 1-24, Jan. 2010, doi: 10.1016/j.edurev.2009.12.002.

[7] Hsiao A. C. 'SUSTAINABILITY IN ENGINEERING DESIGN', Proceedings of the Canadian Engineering Education Association (CEEA), Nov. 2019, doi: 10.24908/pceea.vi0.13877.

[8] Staniškis J. K. and Katiliūtė E. 'Complex evaluation of sustainability in engineering education: case \& analysis', Journal of Cleaner Production, vol. 120, pp. 13-20, May 2016, doi: 10.1016/j.jclepro.2015.09.086.

[9] Nikolić V. M. and Tamara M. V. 'Sustainable development as a challenge of engineering education', in Thermal Science 2020, 2020, pp. P304-304.

[10] Voûte E., Stappers P. J., Giaccardi E., Mooij S., and van Boeijen A. 'Innovating a Large Design Education Program at a University of Technology', She Ji: The Journal of Design, Economics, and Innovation, vol. 6, no. 1, pp. 50-66, Mar. 2020, doi: 10.1016/j.sheji.2019.12.001.

[11] Edvardsson Björnberg K., Skogh I.-B., and Strömberg E. 'Integrating social sustainability in engineering education at the KTH Royal Institute of Technology', International Journal of Sustainability in Higher Education, vol. 16, no. 5, pp. 639-649, Jan. 2015, doi: 10.1108/IJSHE01-2014-0010.

[12] Shields D., Verga F., and Andrea Blengini G. 'Incorporating sustainability in engineering education: Adapting current practices to mining and petroleum engineering education', International Journal of Sustainability in Higher Education, vol. 15, no. 4, pp. 390-403, Jan. 2014, doi: 10.1108/IJSHE-02-2013-0014.

[13] Leifler O. and Dahlin J.-E. 'Curriculum integration of sustainability in engineering education - a national study of programme director perspectives', International Journal of Sustainability in Higher Education, vol. 21, no. 5, pp. 877-894, Jan. 2020, doi: 10.1108/IJSHE-09-2019-0286.

[14] Tardif J. 'Développer un programme par compétences: de l'intention à la mise en œuvre', p. 9, 2003.

[15] Covill D., Katts T., Smith S. and Hicks D. 'EVALUATING INDIVIDUAL CONTRIBUTIONS TO GROUP PROJECTS', DS 104: Proceedings of the 22nd International Conference on Engineering and Product Design Education (E\&PDE 2020), VIA Design, VIA University in Herning, Denmark. 10th -11th September 2020, 2020. https://www.designsociety.org/publication/43234/EVALUATING+INDIVIDUAL+CONTRIBU TIONS+TO+GROUP+PROJECTS (accessed Feb. 24, 2021). 